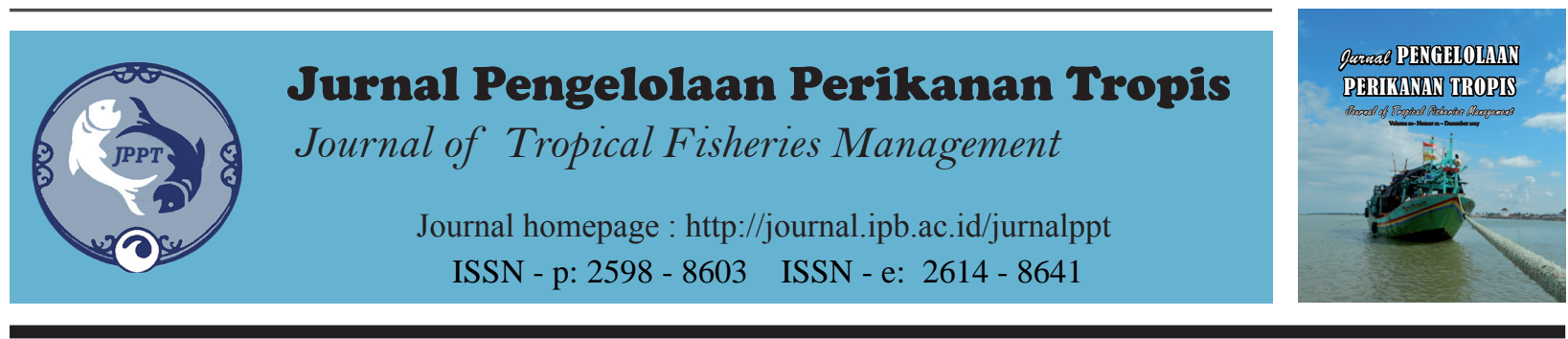

\title{
Indek dan Status Keberlanjutan Pulau Kecil Terluar: Studi Kasus Pesisir Pulo Raya Aceh Jaya
}

(Index and Sustainability Status of Small Outer Island: Case Study of Pulo raya Aceh jaya Coastal)

\author{
Edwarsyah $^{1}$, Rina Safrina ${ }^{1}$
}

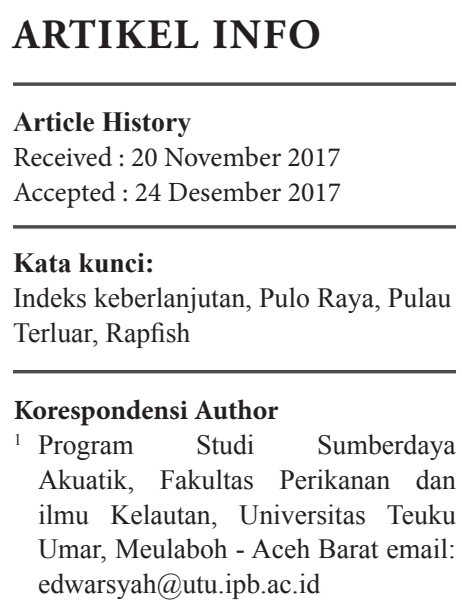

\begin{abstract}
ABSTRAK
Pulau-pulau kecil merupakan sebuah kawasan yang memiliki risiko dan terkena dampak dari perubahan lingkungan. Keterbatasan pulau kecil seperti ukuran yang kecil, marginalitas, dan insularitas yang dimiliki menjadikan pulau kecil memiliki risiko yang sangat tinggi terhadap perubahan lingkungan. Tujuan dari penelitian ini yaitu mengidentifikasi potensi sumberdaya alam pesisir Pulau Pulo Raya dan menilai status indeks keberlanjutan pesisir Pulau Pulo Raya. Analisis keberlanjutan dilakukan dengan pendekatan Rapfish. Analisis Rapfish yang dilakukan pada lima dimensi (ekologi, ekonomi, sosial budaya, teknologi, dan kelembagaan). Atribut pada tiap-tiap dimensi/faktor yang paling berpengaruh adalah kondisi lingkungan perairan (dimensi ekologi); tingkat keuntungan budidaya rumput laut (dimensi ekonomi); kebersamaan sosial (dimensi sosial budaya); jenis kenderaan (dimensi teknologi); serta ketersediaan kelompok perikanan.
\end{abstract}

\section{PENDAHULUAN}

Pulau-pulau Kecil Terluar(PPKT) merupakan Kawasan Stratagis Nasional Tertentu (KSNT) yang memiliki peran strategis dalam kepentingan pertahanan dan keamanan karena berada di beranda depan NKRI. PPKT juga memiliki potensi sumberdaya alam dan jasa lingkungan yang tinggi. Hal ini dikarenakan PPKT pada umumnya terdapat ekosistem terumbu karang, padang lamun (seagrass), mangrove, rumput laut, perikanan pelagis, dan lain-lain (Muhtadi 2016). Keterbatasan PPKT dengan ukuran pulau yang kecil, jauh dari main land (marginalitas) dan insularitas yang dimiliki menjadikan pulau kecil memiliki risiko yang sangat tinggi terhadap perubahan lingkungan.

Ancaman dan degradasi terhadap sumberdaya dan eksosistem PPKT memiliki konsekuensi terhadap hilangnya mata pencaharian penduduk
(Adrianto 2004; Rangkuti et al. 2017). Lebih lanjut Muhtadi (2016) menyebutkan pengelolaan PPKT dihadapkan pada berbagai ancaman dari berbagai aspek. Pada aspek ekologi ancaman tersebut, yaitu terjadinya penurunan kualitas lingkungan, seperti pencemaran, perusakan ekosistem, dan penangkapan ikan yang berlebihan (overfishing). Pada aspek sosial-ekonomi, yaitu rendahnya aksesibilitas dan kesejahteraan masyarakat lokal. Oleh karena itu, mengantisipasi perubahan dan ancaman tersebut, pemanfaatan PPKT harus dilakukan secara komprehensif, terpadu, dan berkesinambungan.

Pulo Raya atau Pulau Raya merupakan salah satu PPKT yang terdapat di Provinsi Aceh, tepatnya di Kabupaten Aceh Jaya berdasarkan Keputusan Presiden Republik Indonesia Nomor 6 Tahun 2017 tentang Penetapan Pulau-pulau Kecil Terluar. Pulo Raya berjarak $1 \mathrm{~km}$ dari Lhok Kruet (Aceh Jaya) dengan jarak tempuh speed 


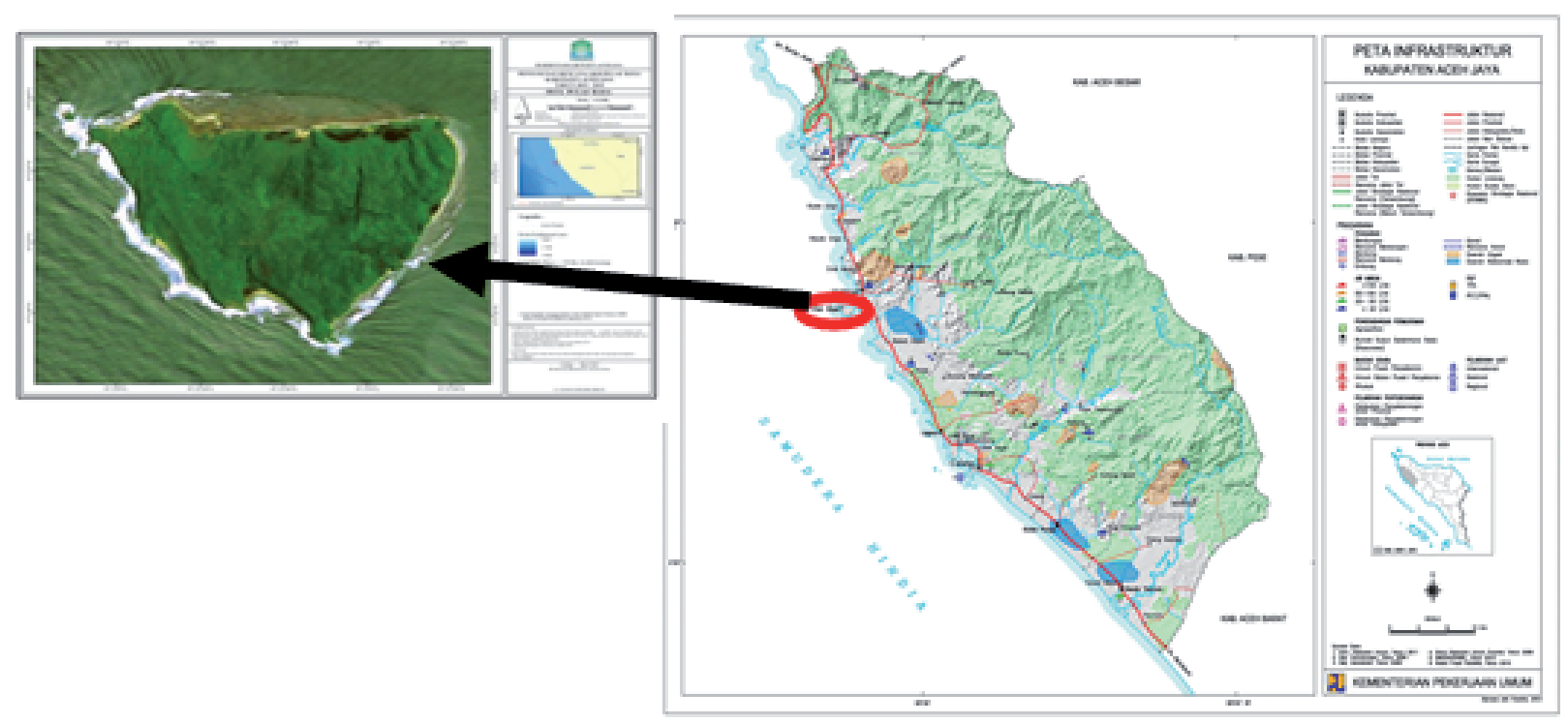

Gambar 1 Lokasi penelitian di Pulau Pulo Raya, Aceh

boad sekitar 10 menit. Pulo Raya memiliki luas wilayah sebesar $2 \mathrm{~km}^{2}$ dengan elevasi ketinggian Pulo Raya antara 0-30 m di atas permukaan laut. Sebelum tsunami (2004), Pulo Raya merupakan pulau berpenghuni, namun akibat tsunami tersebut banyak penduduk yang meninggal dan sebagian yang selamat mengungsi di peisisr Aceh Jaya, Desa Lhook Kruet.

Pulau ini memiliki panorama dan keadaan alam yang asri dengan pohon-pohon cemara yang rindang, pantai pasir yang putih bersih, dan keanekaragaman karang yang cukup tinggi. Pulo Raya merupakan salah satu destinasi wisata bagi masyarakat Aceh Jaya. Selain itu, Pulo Raya merupakansalah satudaerah penangkapanikan bagi nelayan di perairan Aceh Jaya. Wilayah perairan Pulo Raya juga berpotensi sebagai kegiatan budi dayarumput laut dan keramba jaring apung (KJA). Adanya berbagai kegiatan tersebut hendaknya memperhatikan keberlanjutan sumberdaya alam (ekologi). Keberlanjutan eko-logi tercapai jika memperhatikan kondisi sosial ekonomi dan teknologi yang dikembangkan. Dalam hal ini, pembangunan berkelanjutan merupakan integrasi dari tiga aspek, yakni kelestarian sosial, kelestarian lingkungan, dan keberlangsungan ekonomi (Adrianto et al. 2004; Daulay 2011). Mengingat pentingnya kajian keberlanjutan pulau-pulau kecil, khususnya PPKT perlu dilakukan penelitian tentang analisis keberlanjutan untuk mengetahui indeks keberlanjutan potensi sumberdaya alam pesisir Pulau Raya.

\section{METODOLOGI}

\section{Lokasi Penelitian}

Pelaksanaan penelitian ini dilaksanakan selama 4 bulan, yaitu dimulai pada bulan April 2017 hingga juli 2017. Adapun tempat dan lokasi penelitian ini Desa Pulo Raya, Kecamatan Sampoiniet, Kabupaten Aceh Jaya (Gambar 1).

\section{Pengumpulan data}

Data yang dikumpulkan dalam penelitian ini terdiri atas 5 kategori data, yaitu ekologi, sosial, ekonomi, kelembagaan, dan data teknologi. Pengumpulan data diperoleh dengan cara observasi lapangan melalui wawancara dengan kusioner (Data Primer). Pengumpulan data sekunder dilakukan melalui studi pustaka dengan cara mengumpulkan seluruh informasi yang berkaitan dengan kajian/tujuan penelitian, baik yang berasal dari perpustakaan maupun dari berbagai instansiinstansi terkait dari tingkat desa hingga tingkat provinsi. Jenis data dan metode pengumpulan data secara lengkap disajikan dalam Tabel 1.

\section{Analisis Data}

Penilaian status keberlanjutan pengelolaaan Pulo Raya dilakukan dengan menggunakan metode Rapfish (Alder et al., 2000; Pitcher and Preikshot, 2000). Metode Rapfish (Rapid Appraisal Technique for Evaluating Fisheries Sustainability) yang dikembangkan oleh Fisheries Center, University of British Columbia di tahun 
Tabel 1 Metode pengumpulan data

\begin{tabular}{|c|c|c|c|}
\hline Data & Metode Pengumpulan Data & Data & Metode Pengumpulan Data \\
\hline Dimensi ekologi & & Dimensi ekonomi & \\
\hline Luas perairan & Skunder & Besarnya usaha KJA & Primer \& Skunder \\
\hline Suhu & Primer & Tingkat keuntungan KJA & Primer \& Skunder \\
\hline Kesesuaian rumput laut (RL) & Primer \& Skunder & Tingkat keuntungan budidaya RL & Primer \& Skunder \\
\hline Kesesuaian wisata bahari & Primer \& Skunder & Besarnya usaha budidaya RL & Primer \& Skunder \\
\hline Kondisi lingkungan peraairan & Primer \& Skunder & Penyerapaan Tenagaa kerja KJA & Primer \& Skunder \\
\hline $\begin{array}{l}\text { Kesesuaian keramba Jaring Apung } \\
\text { (KJA) }\end{array}$ & Primer \& Skunder & Penyerapan Tenaga Kerja RL & Primer \& Skunder \\
\hline Curah hujan & Skunder & Kelayakan usaha Perikanan & Primer \& Skunder \\
\hline Dimensi sosial & & Jenis komoditas unggulan & \\
\hline Pelatihan untuk nelayan & Primer \& Skunder & Dimensi kelembagaan & \\
\hline Sosialisai pekerjaaan & Primer \& Skunder & Ketersediaan kelompok perikanan & Primer \& Skunder \\
\hline Tingkat pendidikan & Primer \& Skunder & Tingkat kepatuhan masyarakat & Primer \& Skunder \\
\hline Kebersamaan sosial & Primer & Ketersediaaan lembaga sosial & Primer \& Skunder \\
\hline Nilai kebudaayaan & Primer \& Skunder & Saran dn prasarana & Primer \& Skunder \\
\hline \multirow[t]{2}{*}{ Persepsi masyarakat } & Primer & Efektivitaas kelembagaan & Primer \& Skunder \\
\hline & & legalitaas & Primer \& Skunder \\
\hline \multicolumn{4}{|l|}{ Dimensi Teknologi } \\
\hline Ketersediaan alur pelayaran & Primer \& Skunder & Transfortasi & Primer \& Skunder \\
\hline Peneriman informasi & Primer \& Skunder & Alat tangkap & Primer \& Skunder \\
\hline Tingkaat pengusaan teknologi & Primer \& Skunder & Alat komunikasi & Primer \& Skunder \\
\hline Jenis kenderaan & Primer \& Skunder & & \\
\hline
\end{tabular}

1999. Metode ini dilakukan dengan menilai atribut yang terdapat pada setiap dimensi pengelolaan, dengan tahapan sebagai berikut:

1) Penelitian ini menggunakan 35 atribut dari lima dimensi seperti yang tercantum pada Tabel 1.

2) Setiap atribut diberikan salah satu nilai dari ketiga kategori nilai yang telah ditentukan (1,2,3). Pemberian nilai terhadap setiap atribut memberikan gambaran terhadap kondisi keberlanjutan pengelolaan Pulo Raya, apakah baik ataupun buruk.

3) Ordinasi Rapfish dengan metode MDS (Multidimensional Scaling) digunakan untuk menentukan satu titik (nilai) yang mencerminkan posisi relatif dari pengelolaan Pulo Raya. Hasil analisis yang baik menunjukkan nilai stres yang lebih kecil dari $0,25(\mathrm{~S}<0,25)$.

4) Penentuan status keberlanjutan pengelolaan Pulo Raya berdasarkan pada indeks keberlanjutan perikanan. Indeks keberlanjutan perikanan mempunyai selang antara $0-100$. Nilai indeks keberlanjutan mengacu pada Budianto (2012) yang membagi status keberlanjutan dalam 4 kategori: Tidak Berkelanjutan selang nilai 0-25, Kurang Berkelanjutan selang nilai 26-50, Cukup Berkelanjutan selang nilai $51-75$, dan Berkelanjutan selang nilai 76-100.

5) Analisis Monte Carlodi gunakan untuk mengetahui kestabilan hasil ordinasi Rapfish. Analisis Monte Carlopada metode Rapfish dilakukan sebanyak 25 kali ulangan dengan teknik scatter plot. Kestabilan indeks keberlanjutan yang dihasilkan tercermin oleh plot yang mengumpul, sedangkan jika hasil menunjukkan plot menyebar dapat diartikan terdapat gangguan atau aspek ketidakpastian dalam hasil analisis. Analisis Laverage dilakukan untuk mengetahui atribut apa saja yang sensitif dari seluruh dimensi yang digunakan. Atribut paling sensitif akan memberikan kontribusi terhadap keberlanjutan dalam bentuk perubahan Root Mean Square (RMS) yaitu pada sumbu X (skala keberlanjutan). 


\section{HASIL DAN PEMBAHASAN}

\section{Dimensi Ekologi}

Analisis keberlanjutan dimensi ekologi mencakup tujuh atribut yang merupakan penunjuk keberlanjutan potensi sumberdaya alam pesisir Pulo Raya. Diagram ordinansi Rapfish yang menggambarkan posisi keberlanjutan setiap atribut berdasarkan indeks keberlanjutan potensi sumberdaya alam pesisir di lokasi penelitian yaitu sebesar 56,57. Ordinansi keberlanjutan keseluruhan dimensi ekologi berada pada selang 50,01-75,00 atau mempunyai status "cukup berkelanjutan" dengan indeks keberlanjutan $>50$. Hasil analisis laverage menunjukkan bahwa atribut yang paling sensitif berdasarkan nilai RMS yang merupakan indikator kunci terhadap keberlanjutan kriteria ekologi sebanyak 4 indikator, yaitu: 1) kondisi lingkungan perairan sebesar $(9,56 \%)$; 2) kesesuain KJA sebesar (7,49\%); 3 ) kesesuaian rumput laut sebesar (6,85\%); dan 4) luas perairan sebesar (6,61\%) (Gambar 2).

\section{Dimensi sosial}

Analisis keberlanjutan dimensi sosial budaya mencakup enam atribut yang merupakan penunjuk keberlanjutan potensi sumberdaya alam pesisir Pulo Raya. Diagram ordinansi Rapfish yang menggambarkan posisi keberlanjutan setiap atribut berdasarkan indeks keberlanjutan potensi sumberdaya alam pesisir di lokasi penelitian, yaitu sebesar 54,43. Ordinansi keberlanjutan keseluruhan dimensi sosial budaya berada pada selang 50,01-75,00 atau mempunyai status "cukup berkelanjutan" dengan indeks keberlanjutan $>50$. Analisis leverage dilakukan bertujuan untuk melihat atribut yang sensitif memberikan konstribusi terhadap indeks dimensi sosial budaya. Hasil analisis laverage menunjukkan bahwa atribut yang paling sensitif berdasarkan nilai RMS yang merupakan indikator kunci terhadap keberlanjutan kriteria sosial budaya sebanyak empat atribut, yaitu 1) kebersamaan sosial sebesar $(2,41 \%)$; 2) nilai kebudayaan sebesar $(1,13 \%)$; 3) sosialisasi pekerjaan sebesar $(1,07 \%)$; dan
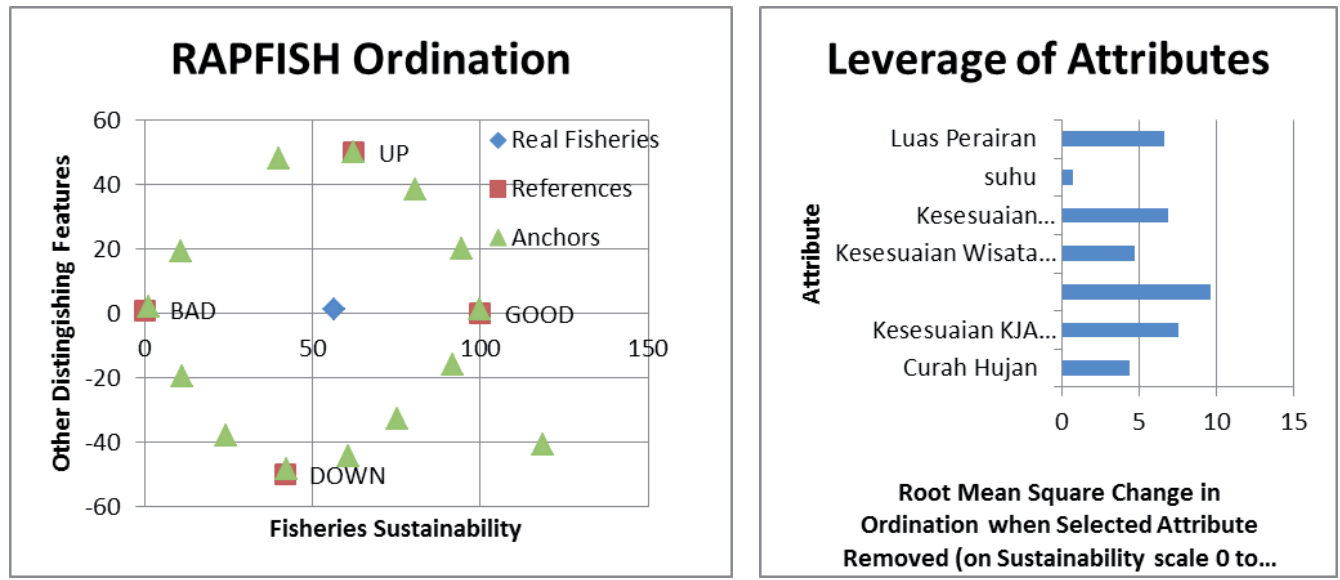

Gambar 2 Status keberlanjutan pada kriteria ekologi
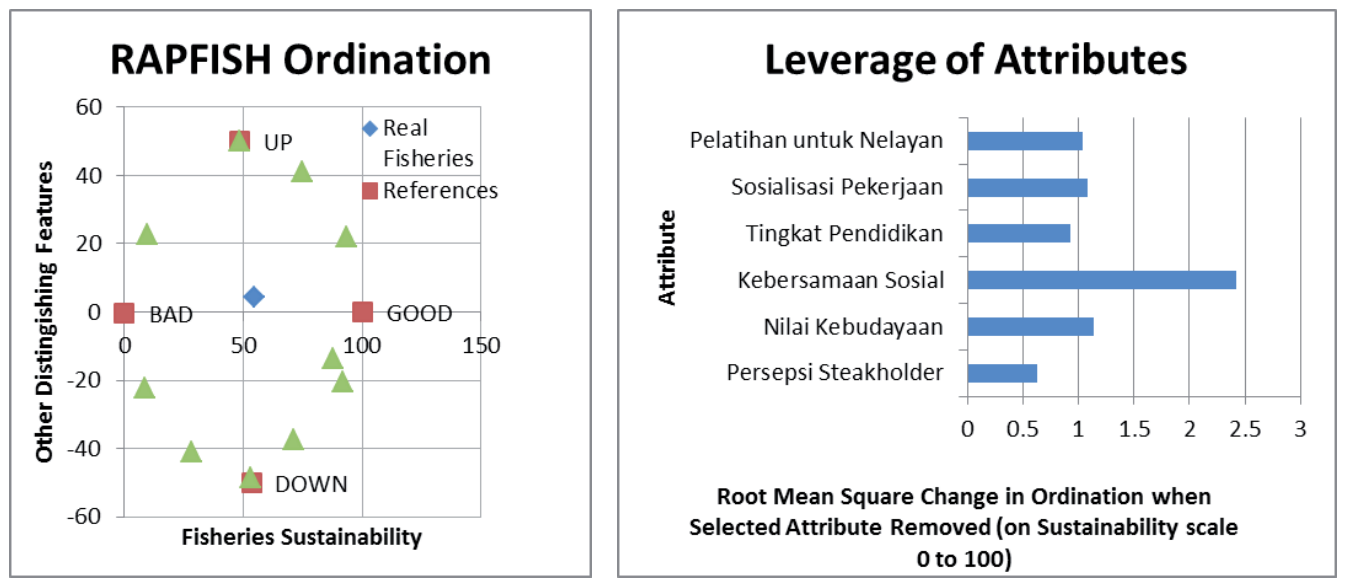

Gambar 3 Status keberlanjutan pada kriteria sosial 
4) pelatihan untuk nelayan sebesar $(1,04 \%)$ (Gambar 3).

\section{Dimensi ekonomi}

Analisis keberlanjutan dimensi ekonomi mencakup delapan atribut yang merupakan penunjuk keberlanjutan potensi sumberdaya alam pesisir Pulo Raya. Diagram ordinansi Rapfish yang menggambarkan posisi keberlanjutan setiap atribut berdasarkan indeks keberlanjutan potensi sumberdaya alam pesisir di lokasi penelitian, yaitu sebesar60,63. Ordinansikeberlanjutankeseluruhan dimensi ekonomi berada pada selang 50,01-75,00 atau mempunyai status "cukup berkelanjutan" dengan indeks keberlanjutan $>50$. Analisis leverage dilakukan bertujuan untuk melihat atribut yang sensitif memberikan konstribusi terhadap indeks dimensi ekonomi. Hasil analisis laverage menunjukkan bahwa atribut yang paling sensitif berdasarkan nilai RMS yang merupakan indikator kunci yang berpengaruh terhadap keberlanjutan kriteria ekonomi sebanyak empat atribut, yaitu
1) tingkat keuntungan budidaya rumput laut sebesar $(4,66 \%)$; 2) penyerapan tenaga kerja budidaya rumput laut sebesar (3,11\%); 3 ) penyerapan tenaga kerja KJA sebesar $(2,92 \%)$; dan 4) kelayakan usaha perikanan $(2,32 \%)$ (Gambar 4).

\section{Dimensi kelembagaan}

Analisis keberlanjutan dimensi ekonomi mencakup enam atribut yang merupakan penunjuk keberlanjutan potensi sumberdaya alam pesisir Pulo Raya pulau-pulau kecil terluar. ordinansi Rapfish yang menggambarkan posisi keberlanjutan setiap atribut berdasarkan indeks keberlanjutan potensi sumberdaya alam pesisir di lokasi penelitian yaitu sebesar 99,99. Ordinansi keberlanjutan keseluruhan dimensi kelembagaan berada pada selang 50,01-75,00 atau mempunyai status "cukup berkelanjutan" dengan indeks keberlanjutan $>50$. Analisis leverage dilakukan bertujuan untuk melihat atribut yang sensitif memberikan konstribusi terhadap indeks dimensi
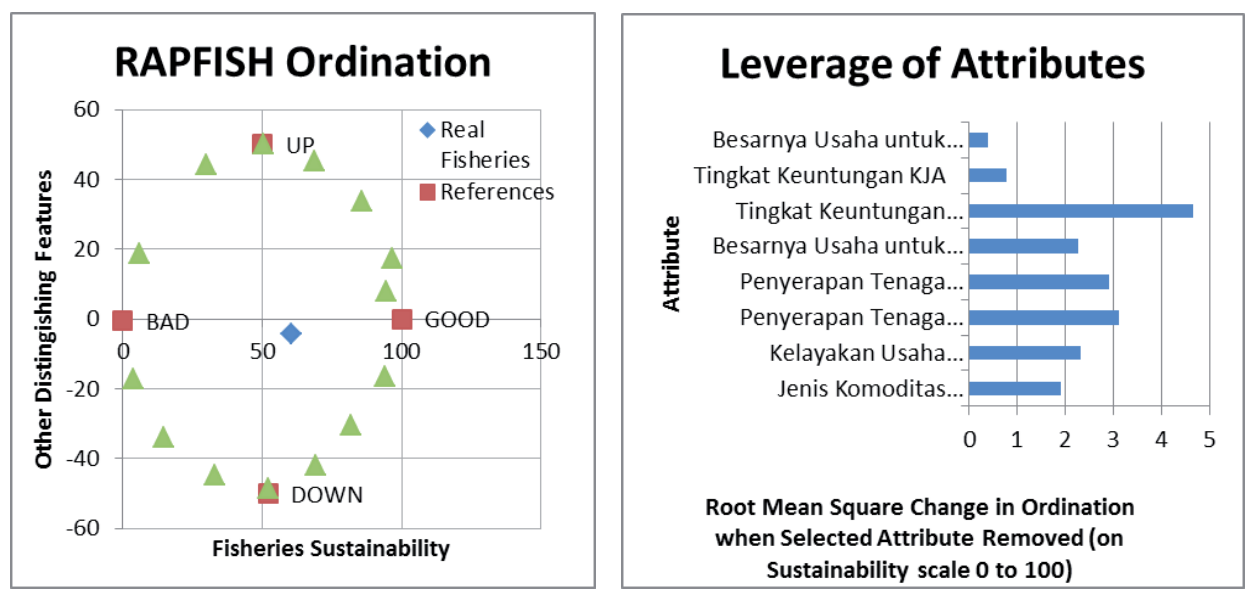

Gambar 4 Status keberlanjutan pada kriteria ekonomi
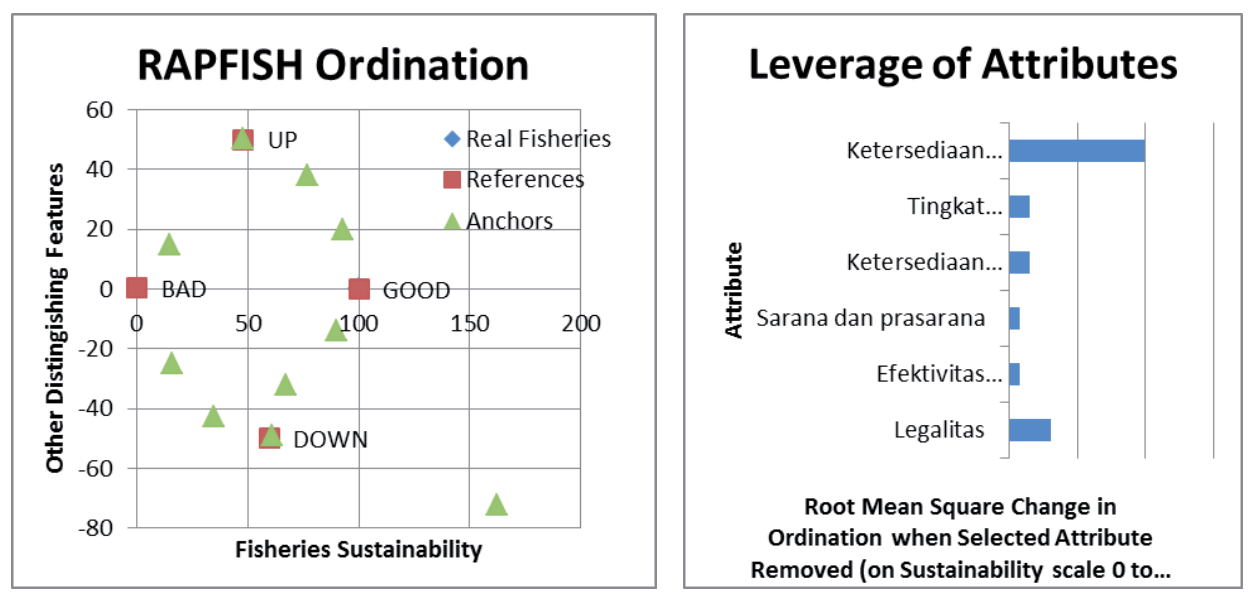

Gambar 5 Status keberlanjutan pada kriteria teknologi 
kelembagaan. Hasil analisis laverage (Gambar 5a) menunjukkan bahwa atribut yang paling sensitif berdasarkan nilai RMS yang merupakan indikator kunci yang berpengaruh terhadap keberlanjutan kriteria kelembagaan sebanyak empat atribut, yaitu 1) ketersediaan kelompok perikanan sebesar $(9,91 \%) ; 2)$ legalitas sebesar $(3,05 \%) ; 3)$ tingkat kepatuhan masyarakat sebesar $(1,52 \%)$; dan 4$)$ sarana dan prasarana sebesar (8,45\%) (Gambar 5).

\section{Dimensi teknologi}

Analisis keberlanjutan dimensi teknologi mencakup tujuh atribut yang merupakan penunjuk keberlanjutan potensi sumberdaya alam pesisir Pulo Raya. Diagram ordinansi Rapfish yang menggambarkan posisi keberlanjutan setiap atribut berdasarkan indeks keberlanjutan potensi sumberdaya alam pesisir di lokasi penelitian, yaitu sebesar 78,58. Ordinansikeberlanjutan keseluruhan dimensi teknologi berada pada selang 50,01-75,00 atau mempunyai status "kurang berkelanjutan" dengan indeks keberlanjutan $>50$. Analisis leverage dilakukan bertujuan untuk melihat atribut yang sensitif memberikan konstribusi terhadap indeks dimensi teknologi. Hasil analisis laverage menunjukkan bahwa atribut yang paling sensitif berdasarkan nilai RMS yang merupakan indikator kunci yang berpengaruh terhadap keberlanjutan kriteria teknologi sebanyak empat atribut, yaitu 1) jenis kenderaan sebesar $(7,07 \%)$; 2) jenis alat tangkap sebesar $(6,20 \%) ; 3)$ tingkat menguasai teknologi sebesar (4,77\%); dan 4) alat komunikasi sebesar (4,72\%) (Gambar 6).

Dari hasil analisis memperlihatkan bahwa dimensi kelembagaan dan ekologi merupakan dimensi yang paling tinggi indeks keberlanjutannya. Nilai atau indeks semakin keluar (mendekati angka 100) menunjukkan status keberlanjutan yang semakin bagus, sebaliknya jika semakin ke dalam (mendekati titik 0) menunjukkan status keberlanjutan yang semakin buruk. Nilai indeks keberlanjutan untuk masingmasing dimensi disajikan pada Tabel 2. Gambar 6 memperlihatkan bahwa nilai indeks keberlanjutan untuk setiap dimensi berbeda-beda, hasil nilai indeks keberlanjutan keseluruhan sebesar 61,65 pada skala sustainabilitas $0-100$ dan termasuk ke dalam kategori cukup berkelanjutan. Nilai ini diperoleh berdasarkan penilaian terhadap 34 atribut dari lima dimensi keberlanjutan. Dalam konsep pembangunan berkelanjutan bukan berarti semua indeks dari setiap dimensi harus memiliki nilai yang sama besar, melainkan dalam berbagai kondisi daerah tentu memiliki prioritas dimensi apa yang lebih dominan untuk menjadi perhatian. Pada prinsipnya, indeks keberlanjutan pada setiap dimensi tersebut berada pada kategori "cukup berkelanjutan".

Hasil kajian ini lebih baik dibanding hasil keberlanjutan pengelolaan Pulau-pulau Kecil di Makassar dengan keberlanjutan hanya 50,99\% (Hasrat et al. 2014). Sementara hasil kajian Fitrianti et al. (2014) terhadap keberlanjutan Perikanan Ikan Terbang di Kabupaten Takalar, Sulawesi Selatan mendapatkan kategori kurang berkelanjutan. Hasil kajian Jeujanan et al. (2015) terkait pengelolaan rumpon keberlanjutan pada dimensi ekonomi di perairan kepulauan Kei Kabupaten Maluku Tenggara dengan kategori cukup berkelanjutan. Aris et al. (2017) juga mendapatkan kategori cukup berkelanjutan dengan analisis dimensi sosial ekonomi pada Taman Wisata Alam Laut (TWAL) Pulau Weh. Demikian juga dari hasil kajian Adriman et al.
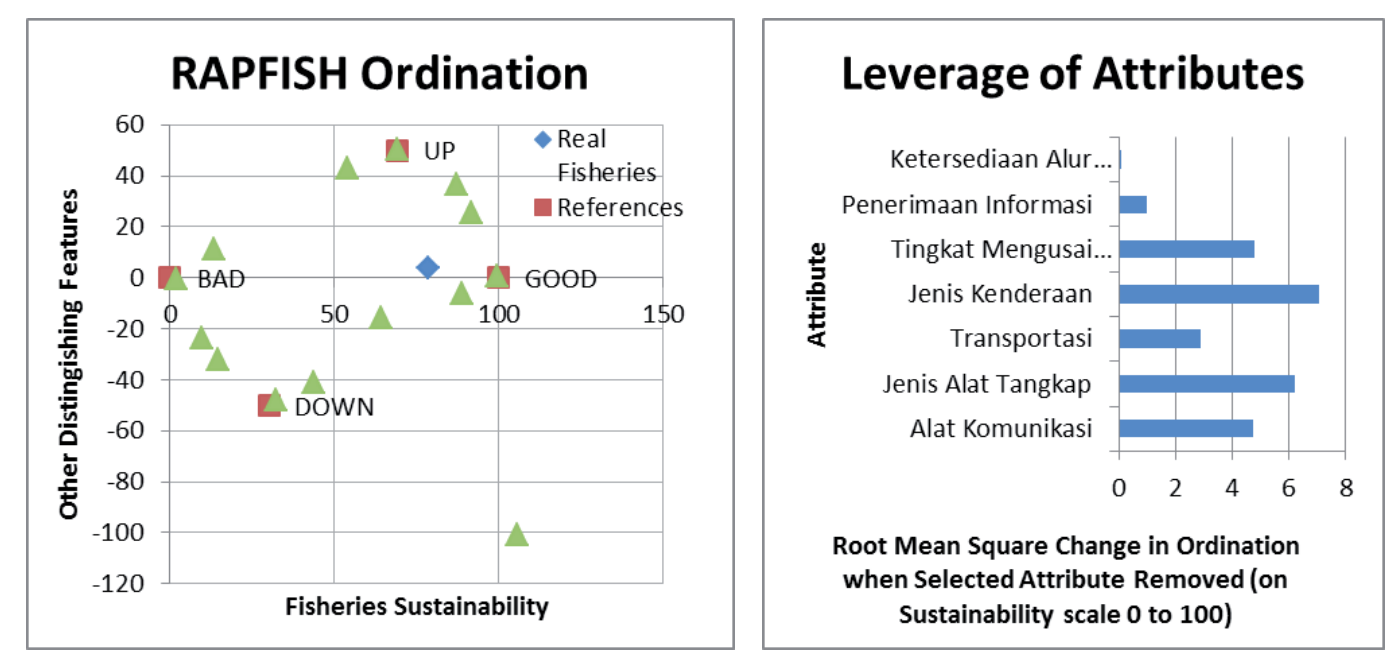

Gambar 6 Status keberlanjutan pada kriteria teknologi 
(2012) mendapatkan keberlanjutan pengelolaan ekosistem terumbu karang di kawasan konservasi laut daerah Bintan Timur Kepulauan Riau dengan kategori cukup berkelanjutan.

Terkait strategi pengelolaan Edwarsyah et al. (2017) menetapkan berbagai prioritas sesuai dengan nilai indeks yang paling rendah. Nilai yang paling rendah merupakan nilai yang menunjukkan perlu adanya tindakan pengelolaan lanjut. Dalam hal ini, rendahnya nilai ekologi dan sosial budidaya menjadi prioritas utama dalam jangka pendek. Untuk dimensi ekologi pentingnya penanaman pohon untuk memberikan kesejukan bagi wisatawan. Sementara terkait sosial pentingnya sosialisasi dan pendekatan terhadap masyarakat terkait pengelolaan Pulo Raya akan kegiatan pembangunan, baik ekowisata maupun kegiatan budidaya.

Tabel 2 Indeks keberlanjutan pada setiap dimensi

\begin{tabular}{|l|r|}
\hline Dimensi & Indeks Keberlanjutan \\
\hline Ekologi & 56,57 \\
\hline Ekonomi & 60,63 \\
\hline Sosial Budaya & 54,43 \\
\hline Teknologi & 78,58 \\
\hline Kelembagaan & 99,99 \\
\hline Rata-rata & $\mathbf{6 1 , 6 5}$ \\
\hline
\end{tabular}

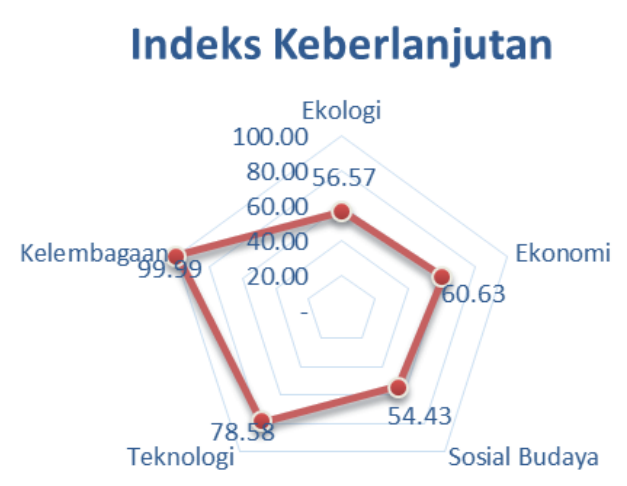

Gambar 7 Diagram keberlanjutan dimensi

\section{KESIMPULAN DAN SARAN}

\section{Kesimpulan}

Analisis Rapfish yang dilakukan pada lima dimensi (ekologi, ekonomi, sosial budaya, teknologi, dan kelembagaan) menunjukkan kategori status cukup berkelanjutan (ikp terendah 54,43-99,99 atau berada pada selang 50,01$75,00)$. Atribut pada tiap-tiap dimensi/faktor yang paling berpengaruh adalah kondisi lingkungan perairan (dimensi ekologi); tingkat keuntungan budidaya rumput laut (dimensi ekonomi); kebersamaan sosial (dimensi sosial budaya); jenis kenderaan (dimensi teknologi); ketersediaan kelompok perikanan.

\section{Saran}

Saran penelitian lanjutan terkait analisis sumberdaya alam pesisir dan analisis usaha masing-masing budidaya keramba jaring apung dan rumput laut, serta pariwisata sehingga secara teknis konsep pengelolaan dapat lebih dikembangkan

\section{DAFTAR PUSTAKA}

Adrianto L. 2004. Pembangunan dan Pengelolaan Pulau-pulau Kecil yang Berkelanjutan. PKSPL IPB. Bogor.

Adriman A. Purbayanto, S. Budiharso, dan A Damar. 2012. Analisis Keberlanjutan Pengelolaan Ekosistem Terumbu Karang di Kawasan Konservasi Laut Daerah Bintan Timur Kepulauan Riau. Jurnal Perikanan dan Kelautan 17(1): 1-15.

Alder J, TJ Pitcher, D Preikshot, K Kaschner, B Ferris. 2000. How good is good? a rapid appraisal technique for evaluation of the sustainability status of fisheries of the north atlantic. In: Pauly and Pitcher (eds). Methods for evaluation the impact of fisheries on North Atlantic ecosystem.Fisheries Centre, University of British Columbia, Vancouver, Canada.

Aris M, A Fahrudin, E Riani. 2017. Analisis Dimensi Sosial Ekonomi Keberlanjutan Pengelolaan Taman Wisata Alam Laut (Twal) Pulau Weh. Jurnal Ilmiah Sains, Teknologi, Ekonomi, Sosial dan Budaya 1(1): 1-7.

Daulay, Zainul. 2011. Pengetahuan Tradisional; Konsep, Dasar, Hukum dan Praktiknya. Jakarta: PT Raja Grafindo Persada.

Edwarsyah, Yonvitner, A Muhtadi. 2017. Pengelolaan Ekosistem dengan Pendekatan Ekosistem (EAFM). Briiliant Press PT Menuju Insan Cemerlang. Surabaya (in press).

Fitrianti RS, MM Kamal, R Kurnia. 2014. Analisis Keberlanjutan Perikanan Ikan Terbang di Kabupaten Takalar, Sulawesi Selatan. Depik 3(2): 118-127.

Hasrat, J Haluan, IK Budiastra. 2014. Status Keberlanjutan Pengelolaan Perikanan 
Budidaya Di Pulau-pulau Kecil Makassar. Jurnal Manajemen Perikanan dan Kelautan 1(1): 1-14.

http://www.ppk-kp3k.kkp.go.id/direktori-pulau/ index.php/public_c/pulau_info/449

http://acehjayakab.go.id diakses pada tanggal 3 November 2016

Jeujanan BS Martasuganda, MFA Sondita, R Yusfiandayani, Monintja. 2015. Pengelolaan Rumpon Keberlanjutan pada Dimensi Ekonomi di Perairan Kepulauan Kei Kabupaten Maluku Tenggara. Jurnal Ilmu dan Teknologi Kelautan Tropis 7(2): 613-627.

[Kep Pres] Keputusan Presiden Republik Indonesia Nomor 6 Tahun 2017 tentang Penetapan Pulau-pulau Kecil Terluar.
Muhtadi A. 2016. Pemanfaatan Berkelanjutan Pulau-pulau Kecil Terluar dengan Konsep Ekowisata Bahari (Studi Kasus: Pulau Wunga, Kabupaten Nias Utara). Prosiding Simposium Nasional Pengelolaan Perikanan Karang Berkelanjutan Indonesia, Kementerian Kelautan dan Perikanan. Hal 262-272.

Pitcher TJ, D Preikshot. 2000. RAPFISH: A rapid appraisal technique to evaluate the sustainability status of fiheries. Fisheries Research 49(2001). Fisheries Centre, University of British Columbia, Canada.

Rangkuti AM, MR Cordova, A Rahmawati, Yulma, EH Adimu. 2017. Ekosistem Pesisir dan Laut Indonesia. Jakarta: PT Bumi Aksara. 482 hal. 